\title{
SPECIALISATION AND PROMOTION IN THE ROMAN IMPERIAL
}

ARMY

BY

\author{
MICHAEL ALEXANDER SPEIDEL
}

Did professional specialisation increase the chances of promotion within the Roman army? And if so, what were the benefits of such a promotion?' The Roman imperial army was a professional organisation with many specialists amongst the ordinary soldiers - so many specialists, in fact, that it may even seem difficult to define the ordinary soldier. For every soldier had a specific task assigned to him, depending on his unit and his position in the battle line. Auxiliary soldiers, in particular, were often highly specialised. Many of them fought in the light infantry units where some were specialised in fighting with different kinds of spears and javelins, others with axes, bows or slings etc. Auxiliary horsemen, too, were highly specialised soldiers, some fighting in light, others in heavy cavalry units, and again with many of them additionally specialised in certain weapons. Even legionary soldiers were very often specialised in fighting with particular weapons. By the third century the specialisation of weapon-skills in the legions was such that we find lancearii, phalangarii, sagittarii, triarii, equites and others attested on inscriptions. ${ }^{2}$ However, such specialists remained ordinary soldiers, as achieving skills in certain fighting techniques did not lead to promotion. There is only one exception to that rule: for an infantry soldier becoming a horseman was indeed a promotion. This is clear from a number of soldiers' careers, and from the fact, that horsemen earned higher pay. ${ }^{3}$ Transfer to a troop of higher rank was also considered a promotion, and it may well have entailed training in new fighting techniques. ${ }^{4}$ However, there is nothing to show that the mastery of such techniques was required before promotion and transfer. At this level all were considered ordinary soldiers. In the infantry

\footnotetext{
${ }^{1}$ For a useful recent summary on the ranks, careers, the recruitment, the social and financial standing of soldiers and veterans etc. cf G. Wesch-Klein, Soziale Aspekte des römischen Heerwesens in der Kaiserzeit (Stuttgart 1998), as well as the numerous contributions in G. Alföldy/B. Dobson/W. Eck (ed.), Kaiser, Heer und Gesellschaft in der Römischen Kaiserzeit. Gedenkschrift für Eric Birley (Stuttgart 2000).

${ }^{2}$ Cf. M.P. Speidel, The Framework of an Imperial Legion (Cardiff 1992).

${ }^{3}$ M.A. Speidel, 'Roman Army Pay Scales', Journal of Roman Studies 82 (1992), $92 \mathrm{f}$.

${ }^{4}$ M.A. Speidel, 'Sold und Wirtschaftslage der römischen Soldaten', in: Alföldy/Dobson/Eck 2000, op.cit. (n.1), $68 \mathrm{f}$.
} 
the official term for them was miles, miles gregarius, pedes or munifex, ${ }^{5}$ in the cavalry eques or gregalis. As all ordinary soldiers in the Rome cohorts, the legions and in the auxilia, regardless of their individual weapons' skills, were described by these general terms, they were not the true specialists of the Roman army.

In all regular units a certain number of soldiers were exempt from some of the heavier fatigues everyone else had to perform. Though the term immunis by which these soldiers were eventually described may not have been in use during all of the first century $\mathrm{AD}$, the principle as such may well have been. It is at this level that we find a great number of specialists. The jurist Tarrutienus Paternus, in his first book on military matters, defines the term immunis and adds a list of such soldiers. Though his list contains a wide variety of such immunes it does not appear to have been intended to be exhaustive. Also, this list is to be taken as typical of Paternus' own time, that is: the late second century, and not all of it may be true of an earlier period. It may be worth while to quote the passage, as recorded in the Digests, in full:

Some are entitled by their conditions of service to relief from the heavier fatigues. These are men such as the surveyors, the optio of the hospital, the surgeons and dressers, the artisans and those who dig the ditch, veterinary officers, the architect, pilots, shipwrights, artillery-builders, glassfitters, craftsmen, arrowsmiths, coppersmiths, shield-boss-makers, wagon-makers, shinglers, swordsmiths, water engineers, trumpet-makers, hornmakers, plumbers, blacksmiths, masons and lime burners, wood cutters and charcoal burners. In the same category are usually included the butchers, the huntsmen, the keepers of sacrificial animals, the optio of the workshop, those who are in charge of the sick-bay, also clerks (librarii) who are capable of teaching, granary clerks, savings-bank clerks, clerks responsible for monies left without heirs, the assistants to the cornicularii, grooms, the polliones, the weapon-keepers, the herald and the trumpeter. All these are classed among the immunes. ${ }^{6}$

${ }^{5}$ ILS 2055 and 2332; Vegetius, Epitoma rei militaris 2.7 and 19; A. Von Domaszewski, Die Rangordnung des römischen Heeres. 2. durchgesehene Auflage. Einführung, Berichtigungen und Nachträge von B. Dobson (Cologne 1967), 24; R. Marichal, Les Ostraca de Bu Njem (Paris 1992), 68 and $88 \mathrm{f}$.

${ }^{6}$ Dig. 50.6.7. 
Tarrutienus Paternus' list can easily be enlarged as inscriptions and papyri mention various other ranks and functions that are also to be counted among the immunes. Generally speaking, these functions were mainly administrative or technical. Both fields of activity, administration as well as construction or fabrication, were of course vital to the proper functioning of any Roman military unit. The larger the unit, the more important those activities were. Those immunes with administrative duties mainly worked as assistants or secretaries. The areas of fabrication and construction included anything from surveying or constructing entire lock systems along rivers, to the repair of helmets or the fabrication of shoes. For, in principle, the Roman legions were to be capable of supplying themselves with everything they needed.' Flavius Josephus confirms this principle with his statement that every legionary fortress had an artisan quarter, and Vegetius supplies an impressive list of the activities performed within them. ${ }^{8}$ In many ways archaeology and epigraphy have confirmed this information. Obviously, such activities were of great importance in and around the permanent military camps. But many technicians and craftsmen were also needed during warfare, and thus every major military expedition included a considerable number of them. They were needed for various different bookkeeping jobs, for building camps, war machines or other constructions useful during sieges. The forts and the siege ramp at Masada, for instance, are an impressive example of their work. However, the book keepers, technicians, architects, surveyors and craftsmen of the legions were not always exclusively working for their unit's own needs. For, whenever the emperor or a provincial governor wished, they could send the army's specialist technicians to assist in public building projects. ${ }^{9}$ Thus many roads, bridges, tunnels, aqueducts and various types of public buildings were constructed mainly for the use of civilians. Trajan even had the colony of Thamugadi set up by soldiers of legio III Augusta. ${ }^{10}$

A fair number of documents illustrate the specialist function of librator. The librator was a surveyor or leveller, ranking among the immunes

\footnotetext{
${ }^{7}$ Vegetius, Epitoma rei militaris 2.11 .

${ }^{8}$ Josephus, Bellum Iudaicum 3.5.2. Vegetius, Epitoma rei militaris 2.11. It may be noted though, that perhaps not all areas of construction listed by Vegetius were predominantly preformed by army specalists. Some, like the fabrication of new weapons, may rather have been carried out by civilian workmen before the third c. AD.

${ }^{9}$ Cf. Dig. 1.16.7.1. R. MacMullen, Soldier and Civilian in the Later Roman Empire (Cambridge, Mass. 1963), 32 ff.; R. Davies, Service in the Roman Army (Edinburgh 1989), 64.

${ }^{10}$ CIL VIII 17842 and 43.
} 
and specialised in measuring and calculating height differences as well as in drawing up plans for certain constructions, such as aqueducts, ${ }^{11}$ and locks. Libratores could be found in the legions and in the praetorian cohorts. ${ }^{12}$ While Pliny was governor in Bithynia, he repeatedly asked Trajan to send him such a specialist. ${ }^{13}$ The technician Pliny was asking for was to help with the construction of a channel and several locks between a lake near Nicomedia in Bithynia and the sea. Obviously such an undertaking required considerable skill and experience, as there was a danger that the lake might empty into the sea. Pliny, who had no legions under his command was convinced that there was no such specialist to be found in his province who was able enough to successfully complete the task. He was hoping, therefore, that Trajan would send him one from the capital. The emperor, however, arranged to have a surveyor sent over from Moesia inferior. That province had a legionary garrison, and therefore, according to Trajan, such specialists could easily be found there.

A similar case is recorded on the inscription of a funerary monument from Lambaesis in the province of Africa. ${ }^{14}$ The text consists of copies of a series of official letters, as well as additional explanations. It was intended, as it claims, to commemorate the surveying work of Nonius Datus, a former soldier of legio III Augusta. Though the text is not complete, the story Nonius Datus tells can be reconstructed. In 137 the legionary surveyor (librator) Nonius Datus received the task to draw up a precise plan for the construction of a water tunnel at Saldae in the province of Mauretania Caesariensis. After the plan was approved by the local governor Nonius Datus instructed the local workmen, such that they could complete the project on their own. For, like Bithynia, Mauretania Caesariensis only had an auxiliary garrison, and Nonius Datus was apparently needed back at Lambaesis. Some ten years later the local work men had run into difficulties. Starting form both sides of the mountain the two tunnelling companies had failed to meet, and the added length of both tunnels now exceeded the diameter of the mountain. The governor of Mauretania Caesariensis, therefore, asked the legate of legio III Augusta to send Nonius Datus back. Datus, in the meantime, had completed his regular military service, and was now continuing his engagement with the army as an evocatus. It may be

\footnotetext{
${ }^{11}$ Cf. AE 1973, $646=$ AE 1942/43, 93.

${ }^{12}$ CIL VI 2454 = ILS 2060.

${ }^{13}$ Plinius, Epistulae $10.41 \mathrm{f}$. \& $61 \mathrm{f}$.

${ }^{14}$ CIL VIII $2728=$ ILS 5795 = AE 1941, 117
} 
noted that evocatio from the legions was a rare distinction that probably entailed better service conditions and higher pay. ${ }^{15}$ Soon after his return to Saldae, however, Datus fell ill and and had to leave again. A third request for his presence became necessary. By now Datus was a veteran. He returned with soldiers of the fleet and of the auxilia. Nevertheless, he and his companions were attacked by robbers on their way to Saldae, and Nonius Datus was even wounded. When they finally arrived, Datus allocated the remaining work, thereby making use of the rivalry between the soldiers of the fleet and those of the auxilia. Soon after, in 152 the project was finally completed. Clearly, Nonius Datus was a man of great skill and experience, and specialists of his calibre were apparently hard to come by in North Africa.

Like other technicians libratores, too, were needed on military expeditions. Caracalla, for example, had a librator on his Parthian expedition. This is clear from another inscription found at Lambaesis in North Africa. ${ }^{16}$ That text records a list of soldiers and specialists of legio III Augusta that had returned home safely from the expedition in 219. The librator Iulius Felix, and all other participants were handsomely rewarded by Elagabal. Trajan, too, had surveyors on his own expedition against the Parthians. That becomes clear from an instance recorded by Cassius Dio. ${ }^{17}$ During his march on the Parthian capital Trajan wanted to build a channel between the rivers Euphrates and Tigris for an easy down-river transport of his fleet. He had a survey conducted but was then forced to abandon the project because of the different heights of the two rivers. The specialists who conducted this survey may well have been soldiers of the praetorian guard or the legions. Had it been possible to construct such a channel in the little time available during the expedition, then Trajan would have managed to impress his contemporaries with a master-piece of Roman architecture comparable to the bridge he had built over the Danube during his war against Decebalus.

Clearly, libratores were specialists of great skill and experience. The same is also true for most other immunes specialists. But what about their rank within the army and their prospects of promotion? Interestingly, becoming an immunis was technically not a promotion, as this step neither entailed a higher rank nor higher pay. It was, however, a privilege, and as

${ }^{15}$ D. Breeze/B. Dobson, Roman Officers and Frontiers (Stuttgart 1993), 106; E. Birley, The Roman Army. Papers 1929 - 1986 (Amsterdam 1988), $326 \mathrm{f}$.

${ }^{16}$ CIL VIII $2564=$ VIII 18052.

${ }^{17}$ Dio 68.28.1. 
such highly valued. The removal of that privilege, the munerum indictio, therefore, was a punishment. ${ }^{18}$ The immunitas from the munera graviora was, in fact, the first important distinguishing mark that separated those with a privileged position from the ordinary soldiers. ${ }^{19}$ Paternus' lengthy list of immunes specialists quoted above may give the impression that only few soldiers remained for normal duty. That, however, is a false impression. Though it is impossible to say exactly how many soldiers of a given unit were counted among the immunes, the little evidence we have suggests, that perhaps only about $10 \%$ of all soldiers within a legion enjoyed this status. ${ }^{20}$ The majority of soldiers therefore remained at the basic level of miles gregarius or munifex.

What exactly did the privilege of the immunes consist of? At times they worked side by side with the munifices. That was the case with the soldiers of legio III Augusta working on the early construction stages of the colony of Thamugadi. A Latin papyrus of the second or third century from Egypt shows that immunes could be employed together with various different types of soldiers, and even civilians in the fabricae of the legions. ${ }^{21}$ That text lists immunes, ordinary legionary soldiers, soldiers from auxiliary cohorts, soldiers' servants, and civilians. Of the numbers that were once recorded in this list, only the one for the legionary soldiers has survived. They counted 100. Nor does the papyrus specify the tasks of the different groups employed in the fabrica. It is likely, however, that the immunes with their specialist skills held senior positions. Travelling, too, may have been considered to be part of the privilege enjoyed by the immunes. Nonius Datus' story, however, shows that travelling also had its risks. Furthermore, the immunes were not freed from the regular exercises and manoeuvres, as their immunitas only concerned the munera graviora, the heavier fatigues. Though the immunes may only have enjoyed limited privileges, it is easy to understand why their status was so highly valued, when the heavy fatigues of the ordinary soldiers consisted of such things as work in Near Eastern quarries. C. Iulius Apollinaris, a soldier of legio III Cyrenaica, based at Petra in Arabia, for instance, wrote the following lines in 107 home to Egypt to his father, a legionary standard-bearer:

\footnotetext{
${ }^{18}$ Dig. 49.16.3.1.

${ }^{19}$ CIL III 7449; CIL VIII 2564 = VIII 18052 = AE 1978, 889; P.Mich. 454 ii 3.

${ }^{20} \mathrm{Cf}$. CIL VIII 7449.

${ }^{21}$ P.Berol. Inv. 6101 = A. Bruckner/R. Marichal, Chartae Latinae Antiquiores 10 (1974), Nr. 409.
} 
Things are fine with me. While others were breaking stones all day, and doing other things, up until today I have suffered none of this. In fact I asked Claudius Severus, the governor, to appoint me as a clerk (librarius) on his staff; and he said: There is no vacancy, but in the meantime I shall appoint you as a clerk of the legion with expectation of advancement. ${ }^{22}$

With this assignment, Apollinaris went to the cornicularius. As librarius legionis and as an adiutor cornicularii, Apollinaris now ranked amoung the immunes (cf. Paternus' list) and was freed from hard labour in the quarries. In a letter he wrote to his mother in 108 Apollinaris, now transferred to Bostra, happily reports:

I give thanks to Sarapis and Good Fortune, that while all are labouring the whole day through at cutting stones, I as a principalis move about doing nothing. ${ }^{23}$

In a third letter, written over ten years later, Iulius Apollinaris gives his rank as frumentarius legionis III Cyrenaicae. ${ }^{24}$ It is not entirely clear, in which sense Apollinaris used the term principalis in his second letter, as he does not claim to have been promoted from his position as librarius. At some time during the early second century, the term principalis came to describe a soldier of higher rank, earning pay-and-a-half or double pay. These soldiers were junior and senior staff officers, had posts within the army's different branches of administration or were under-officers in their centuries. ${ }^{25}$ It may be, therefore, that Apollinaris had been promoted since his first letter, from his position amongst the immunes to one of a principalis. However, it is also possible that the difference between the terms immunis and principalis was not yet as formalised as it was later. In any case, the post of frumentarius was well above the one of librarius, and later, at least, certainly counted among the principales. ${ }^{26}$

Apollinaris' letters are revealing of several points of interest. $\mathrm{He}$ clearly owed his privileged position as a librarius in legio III Cyrenaica, at least in part, to his ability to read and write. The question must therefore be

\footnotetext{
${ }^{22}$ P.Mich. 466. His father a legionary standard bearer: P.Mich. 485. Cf. K. Strobel, 'Zu Fragen der frühen Geschichte der römischen Provinz Arabia und zu einigen Problemen des Legionsdislokation im Osten des Imperium Romanum zu Beginn des 2. Jh. n.Chr.', Zeitschrift für Papyrologie und Epigraphik 71 (1988), 257 ff.; R. Alston, Soldier and Society in Roman Egypt (1995), 134 f.

${ }^{23}$ P.Mich. 465.

${ }^{24}$ P.Mich. 562.

${ }^{25}$ D. Breeze, in: Breeze/Dobson 1993, op. cit (n.15), 11 ff. and 60 ff.; Wesch-Klein 1998, op.cit. (n.1), $30 \mathrm{f}$.

${ }^{26}$ D. Breeze, in: Breeze/Dobson 1993, op. cit (n.15), 34 f., 37, and $40 \mathrm{f}$.
} 
asked, whether reading and writing were specialist skills. No doubt, literacy was an important promotion criterion in the Roman army, as most positions above that of ordinary soldier required such skills. ${ }^{27}$ This was the case, as Vegetius reports, with standard bearers, for not only had they to be trustworthy men but also literate, as they were responsible for their fellowsoldiers' savings accounts. ${ }^{28}$ The same could be said for a great many other functions held by immunes and principales. Very many soldiers, therefore learned to read and write. Some even before they began their military service. A young Egyptian recruit to the Roman fleet at Misenum, for example, wrote home to his father, saying:

You educated me well and I hope thereby to have quick advancement, if the gods so will..$^{29}$

If he was lucky, we do not know, though literacy may indeed have been of significant help particularly for those hoping for promotion in the fleet and in the auxilia. In the legions and in the Rome cohorts, however, it may have helped somewhat less, as in these troops the ability to read, write and calculate appears to have been rather widely spread even among the ordinary soldiers. ${ }^{30}$ It was, however, not only the purely administrative posts that required literacy. Nonius Datus, too was literate, and he was certainly also able to calculate. Therefore, these skills alone can hardly be described as a true specialisation. They were required for a great variety of posts. Yet, within army administration only very few posts, whether they were held by immunes or principales, required any additional administrative skills. In addition to battle field skills it was, therefore, mainly the degree of general administrative experience and trustworthiness, that decided whether a soldier was eligible for a post among the principales.

In the Roman imperial army, the specialists in the true sense of the word were therefore those immunes with particular technical or medical skills. ${ }^{31}$ The libratores are but one example of such soldiers with rare and highly specialised abilities. There were many more. ${ }^{32}$ Yet, did their skills help further their careers? The Roman Imperial Army is generally

\footnotetext{
${ }^{27}$ M.A. Speidel, Die römischen Schreibtafeln von Vindonissa (Brugg 1996), $57 \mathrm{ff}$.

${ }^{28}$ Vegetius, Epitoma rei militaris 2.20 .

${ }^{29}$ BGU 423.

${ }^{30}$ M.A. Speidel, 'Das römische Heer als Kulturträger', in: R. Frei- Stolba/H.E. Herzig (ed.), La politique édilitaire dans les provinces de l'Empire romain. Ilème - IVème siècles après J.-C. (Bern 1995), $200 \mathrm{f}$.

${ }^{31}$ On the medical doctors of the Roman army cf. J. Wilmanns, Der Sanitätsdienst im Römischen Reich (Hildesheim 1995).

${ }^{32}$ K. Strobel, 'Handwerk im Heer - Handwerk im zivilien Sektor', Ktema 16 (1991), 19 ff.
} 
understood to have offered even to common people the possibility of substantial upward social mobility by promotion to higher ranks. In his book on how to interpret dreams Artemidorus Daldianus explains the dream of giving birth to an eagle - a dream he claims to have been popular with many mothers of his time ${ }^{33}$ According to Artemidorus, it meant that a son with a great future would be born. If he was born poor, he would be a soldier and, with some luck, become the first man of his troop (stratopedarches). That was the rank of primuspilus or praefectus castrorum. Clearly, the legionary centurionate was every soldier's dream, just as every centurion must have dreamt of being promoted to the rank of primuspilus one day. For some, though they were few in numbers, that dream became reality, and examples of staggering careers are on hand. These careers show that it was indeed possible to begin a military career in the ranks of the legions, and to ultimately be promoted to the post of a centurion. Even careers that lead from recruit to primuspilus were not unheard of. Some even made it beyond. ${ }^{34}$

However, during most of the first three centuries $A D$, an ordinary soldier had limited hope even of becoming an immunis. If he already had some of the required skills and possibly even some professional experience, his chances may have been better. For we are told by Vegetius that young men with training and experience in certain professions, such as boar- and deerhunters, carpenters, smiths, wagon-makers, and provision-dealers should be preferred over other recruits. In general, he continues, the young men most able of body and mind are to be recruited into the army. ${ }^{35}$ While a good number of soldiers may have been able to read and write before they began their military service, we do not know, whether Nonius Datus, for example, had any knowledge of levelling before he entered the army. If he did, he would probably have had little difficulties joining. At any rate, it was also possible to learn such abilities, and to further improve them within the army. For the libratores this is clear from the rank of discens libratorum which is recorded on an inscription from North Africa. ${ }^{36}$ Even so, ability and experience alone would not guarantee immunitas from the heavier fatigues. As the first letter of Iulius Apollinaris makes clear, the number of positions

\footnotetext{
${ }^{33}$ Artemidorus Daldianus, Oneirokritika 2.20 .

${ }^{34}$ Cf. e.g. Birley 1988, op.cit. (n.15), 206 ff.; G. Alföldy, 'Das Heer in der Sozialstruktur des Römischen Kaiserreiches', in: Alföldy/Dobson/Eck 2000, op.cit. (n.1), 39 ff.; B. Dobson, Die Primipilares (Bonn 1978), 40 f., now with AE 1985, 735.

${ }^{35}$ Vegetius, Epitoma rei militaris 1.7.

${ }^{36}$ AE 1942/43, $93=$ AE 1973, 646.
} 
with that privilege was limited. One normally had to wait for a position to become free. Recommendation also played a role. Again, the case of Iulius Apollinaris may serve as an example. For he had a whole network of comrades and friends of his father's to support him.

The number of soldiers' careers on record is small. Nevertheless, certain trends can be observed. Once a soldier had reached the level of immunis, his further career very much depended on the particular position he held. Generally speaking, those immunes who worked as assistants and secretaries in one of the many administrative offices appear to have had good promotion prospects. Of course, they had no guarantee of further promotion, but like Iulius Apollinaris, they could hope to become principales, then to rise from those earning pay-and-a-half to those earning double pay. The positions they would then typically hold were those of junior and senior staff officers, under-officers in their centuries, or administrators. Most future centurions saw service both in administrative and tactical posts. Staff positions thereby played a most important role, as it was in these posts that soldiers could most easily win the favour of their superiors, as well as their support for their further career. Promotion prospects for the technical specialists appear to have been considerably worse. According to the evidence available, only very few of them were promoted to principales or to the centurionate. There may be more than one explanation for this. Perhaps the lowly specialist posts were not worth mentioning in career inscriptions. More likely, though, such specialists rarely made careers. Perhaps they lacked the support of senior officers, which the other immunes could win during their time as staff officers. Perhaps their skills and experience were of such value, that they were not considered for promotion to other positions. Or, perhaps both. The latter, however, appears to have been the case for Nonius Datus. He never rose above his specialist function as librator. Most likely, he owed his evocatio to his rare skill and experience, and even as a veteran his high degree of expertise was responsible for a further assignment as a leveller.

Interestingly, those specialists of whom we know that they were promoted to higher ranks, served in the praetorian cohorts. T. Flavius Rufus was most successful. He began his career as an ordinary soldier in an urban cohort, was then transferred to the praetorians and became an architectus. $\mathrm{He}$ managed to continue his career as a tesserarius, before he received several positions as a staff officer. Finally, he held four successive legionary 
centurionates. ${ }^{37}$ C. Aelius Aelianus had a similar start, as he too managed to be promoted from a specialist function, a librator, to tesserarius in the praetorian cohorts. He then received the evocatio, but before he was promoted any further, he died. ${ }^{38}$ The last case is that of T. Aelius Malchus. This soldier was promoted from the post of tector equitum praetorianorum to the antistes sacerdos of the temple of Mars in the praetorian cohort's camp. ${ }^{39}$ Such little evidence allows no general statements. It is possible, however, that the better promotion prospects for the specialists of the praetorian cohorts may have had to do with the fact that these troops were closer to the emperor or because they saw military action more often than others. At any rate, brave deeds and battle field achievements could always lead to rewards and promotion.

As a general conclusion, it appears that specialist skills, abilities and experience in the right professions could help to join the army, and to find a privileged position among the ordinary soldiers. However, they generally appear to have been of no help for those seeking promotion to higher ranks. As a variety of specialists were needed on military expeditions, there was still hope for rewards, and perhaps even promotion. Most specialists, however, retired from the army as ordinary veterans, and received upon discharge the standard package of privileges. Those who were asked to stay on as evocati, like Nonius Datus, must have been very few. For some, perhaps even for many, joining the army was, as such, an advantageous step. For they could enjoy the many profits service in the Roman army offered. If joining the army as an ordinary soldier already counted as a step up the social ladder, is impossible to say. The soldiers of the Roman army formed a society of their own, and there is hardly any reliable evidence to directly compare their social standing with that of any remotely comparable group in civil society. Therefore, it also remains impossible to say, whether specialist immunes were regarded higher by civilians than ordinary soldiers, or not. Those immunes who participated in public building projects, like Nonius Datus, very possibly won the respect of the local civil community. However, Nonius Datus was probably an exception, and most specialist immunes may never have received as much public attention as he has. In fact, his funerary inscription is at least as much a celebration of the attention he received from governors and legionary commanders, as it is of his professional

\footnotetext{
${ }^{37}$ ILS 2082.

38 ILS 2060.

${ }^{39}$ ILS 2090.
} 
achievements. For the majority of his colleagues it was probably true, that only their fellow soldiers could fully appreciate the professional work of their lifetime. The same was, of course, also true for most ordinary soldiers, and that was certainly one of the main reasons, why so many of them preferred to stay near their former units after their discharge.

Bern, September 2000 